$$
\text { في شعر الإهام الشافعي }
$$

$$
\begin{aligned}
& \text { دكتورة / سناء يوسف فتح الباب إبراهيم } \\
& \text { ملدرس بقسم النحو والصرف والعروض } \\
& \text { كلية دار العلوم - جامعة القاهرة }
\end{aligned}
$$




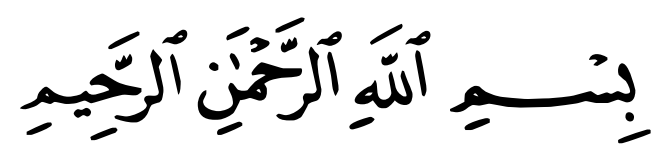

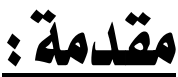

تتمثل الدلالة الصرفية فيما تؤديه الزيادات الصرفية من معان مضافا إليها

معنى الجذر المعجمي، فلو قيل: مرض الطبيب الرجل، لكان المعنى المتعين من هذا الفعل مرض مؤتلفا من معنى الجذر مضافا إليه دلالة هذه الصيخة التي تقيد

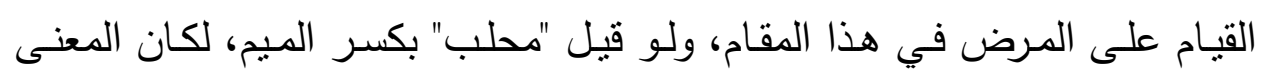
المتعين من هذا اللفظ هو دلالة حلب مضافا إليها دلالة هذه الصيغة الصرفية التي هي تذل على القدح الذي يحلب فيه، وإذا ما قيل محلب فإن المعنى المستفاد بالإضـافة إلى معنى الجذر دلالة صيغة مفعل التي تدل على المكان الذي يحتلب فيه (1)

وهكذا يتبين أن لهذه القوالب الصرفية دورا في تقديم جزء من المعنى، وقد يحدث في بعض الأحبان أن تختلف هذه القوالب الصـرفية دون أن يكون هذا دونا مفضيا إلى اختلاف في المعنى، ومن ذلك مجيء صيغة "فحل وأفعل بمعنى واحد في بعض الأحيان، فيقال: محضته النصح وأمحضته النصح، والمعنى واحد (r). والصيغة في الاصطلاح هي العلامة الصرفية التي تدل على المورفيمات، فمورفيم الطلب تدل عليه صيغة (استفعل) ، ومورفيم التكسير تدل عليه صيغ التيخ التكسير ومورفيم اللزوم تدل عليه صيغة (فعل).(r).

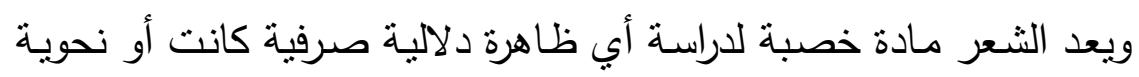
لما يتضمنه من تدفق لمشاعر الحزن أو الفرح أو عرض لتجربة الثـاعر في الحياة

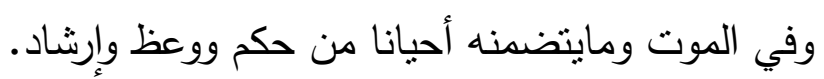


والثعر يتطلب لغـة ومفردات منتقاه للتعبير عن تجربـة الثـاعر ومشـاعره تللك، وأي كلمة ترد في القصيدة الثعرية فهي مقصودة لذاتها ومنتقاه لأداء غرض لنص دلالي معين لايمكن أن يؤديه لفظ آخر .

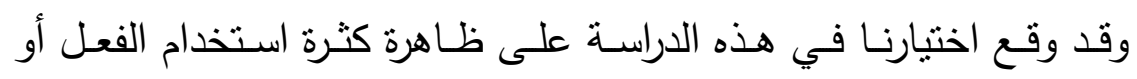
التركيز على صيغة صرفية دون صيغة أخرى في قصائد الإمام الثـافعي وأثز ذلك على المعنى الدلالي الصرفي ومايترتب عليه من إيضاح المعنى العام.

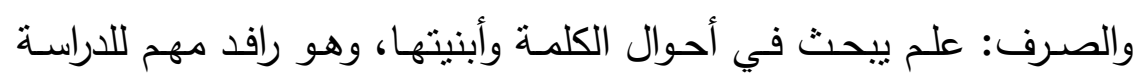

الأسلوبية ذلك لأن كل كلمة لها معنى صرفي مستفاد منها، فعلى سبيل المثال: (المعنى الصرفي للأسماء هو الدلالة على المسمى،.... والمعنى الصرفي للأفعال

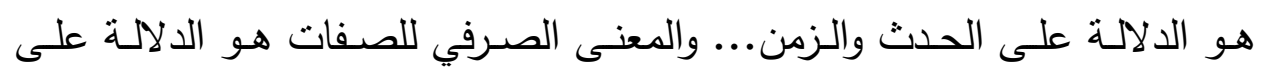
موصوف بالحدث (ع).

ومسن الصـعب تتـاول جميـع هـذه الــلالات الصـرفية للأسـماء والأفعـال

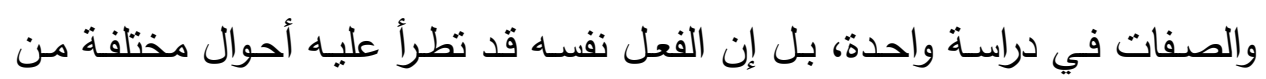

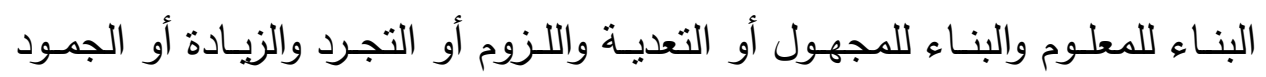
والتصرف...إلخ مما يدعوا إلى تحديد الجانب الذي سنتتاوله الدراسـة، ولمـا كان

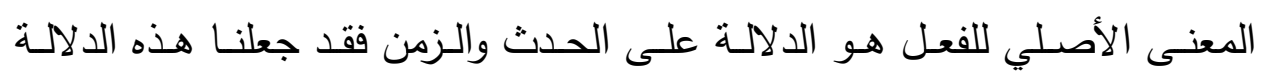
موضوع دراستتا هذه للوصول إلى بيان هذا المعنى الصرفي وأثره في الثـعر من هن خلال قصائد الأمام الثافعي. وهناك فرق بين معاني الفعلِ الخالي عن القيودِ الزمانية، و والفعل المقيَّ بها

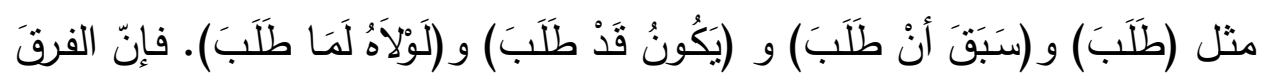
بين هذه التراكيبٍ المختلفةِ واضحةٌ بيّنة.ُ. (0) أما الزّمانُ بالنسبة للفعل، فإنّه جديرٌ بالإهتمام؛ ذلك أن للفعل مراتبُ زمنيةٌ

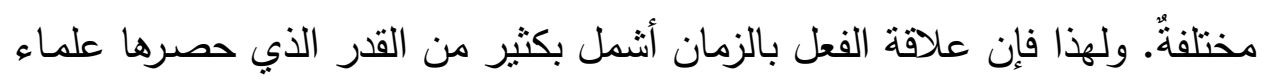

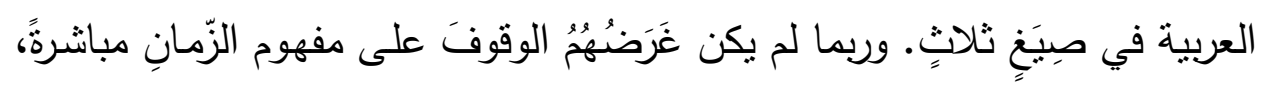




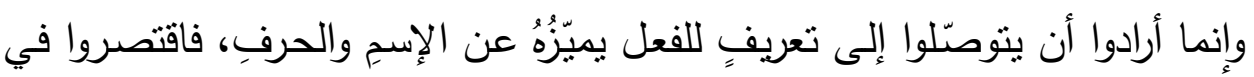

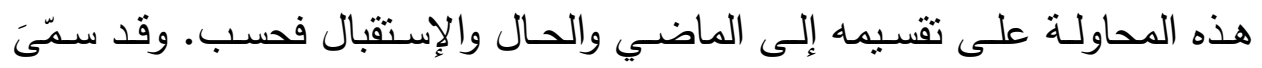

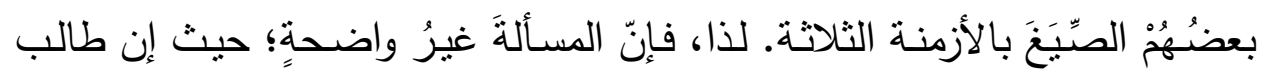
اللّغةِ العربيةِ قد يكون متردِّاً حول هذه القضية، فيتسائل عما إذا كانت هذه التسميةُ

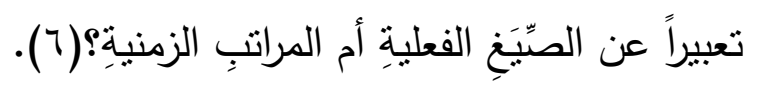

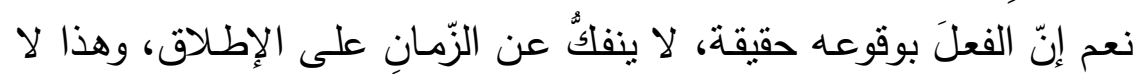

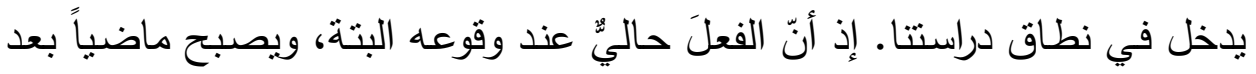
وقوعه حقيقة. وهو مستقبل ما لم يقع. فهذه لا تتعدَّى عن تصورات منطقية بحتة.

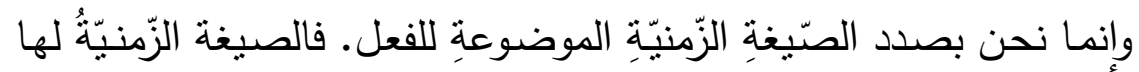

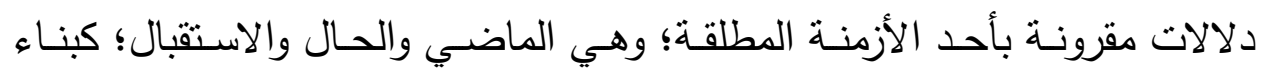
الماضي على الفتح، واستهال المضارع بأحد حروف المضارعة، ودخول السين

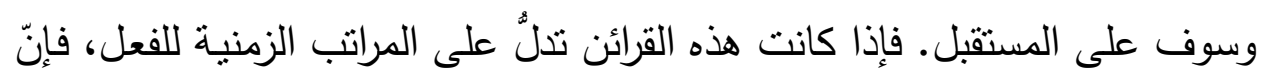

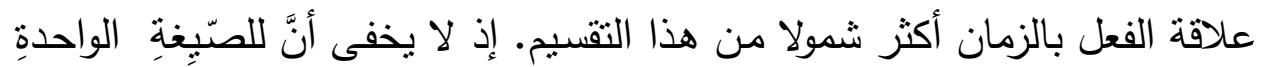

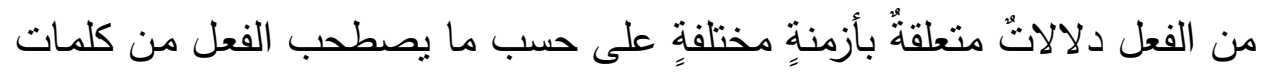

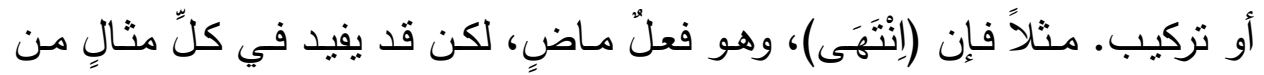

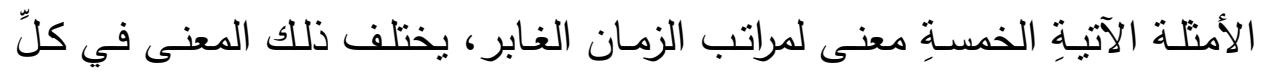

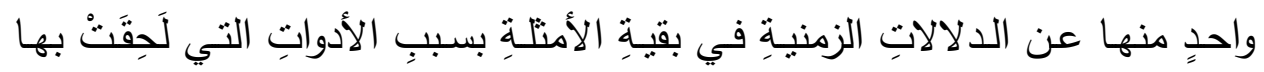

ا. انتهى

r. قد انتهى

r. إذ انتهى

ع. كان قد انتهى

ه. لولاه لما انتهى فحى انتى 


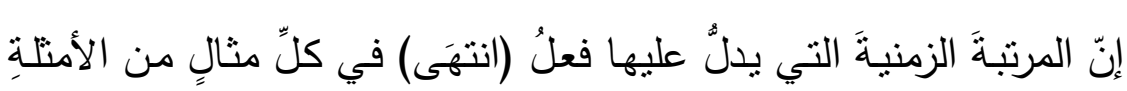
المذكورة، تختلفُ عن بقيَّهِ المراتِب الزّمنيةِ في الأمنتلة الأخرى، مع أن فعل (انتهى)

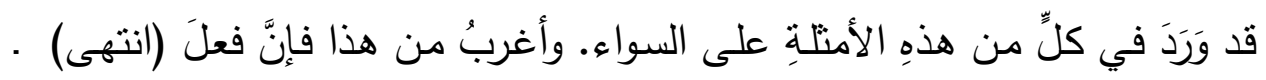
على سبيل المثال ـ في جملة: " إذا انتهى الأجل، انتهى الوجل" يدلّ على مستقبلٍ

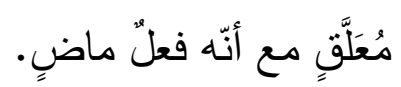

والفعل الماضي قد يخرج في سياقات معينة عن هذه الدلالة الزمنية فهو

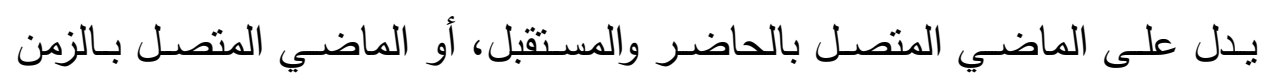
(v) ( الحاضر

وقد يدل على المستقبل في حالات منها: وقوعه في أسلوب الشرط وفي

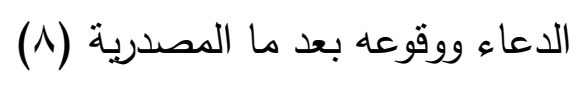

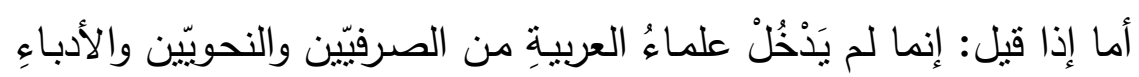
في هذه التفاصبل تجنُباً من النّطوبل في المسائل، وتسهيلاً لطلبةِ العلمِ فإنّ هذا الإعتذار غير مُقْنِع. ويغلب أنّهم قد ركّزوا جُلَّ اهتمامهم على المسائل الإشتقاقيةِ والإعرابيةِ والبلاغيةِ فحسب، وحرصوا في ذلك على تحقيق ثلاثةِة أهدافٍ دون غيرها

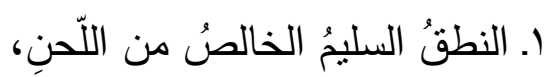

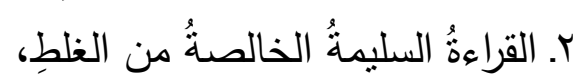

r. الكتابةُ الصحيحةُ الخالصةُ من الخطأ الإملائيِّ والإنشائيِّ.

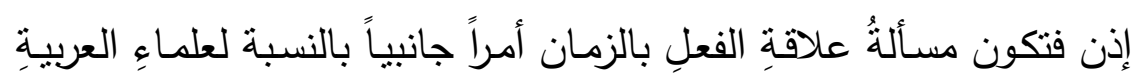

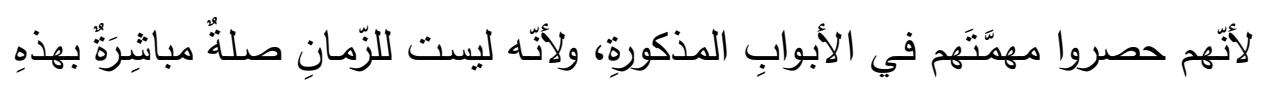

الأبوابِ الثلاثةِ لذلك لم بهتمُّوا بها، وهذا أحسن الظنِّ بهم.

ثم إنها إلى جانب دلالتها على المعنى الصرفي العام للمبنى لها وظائف

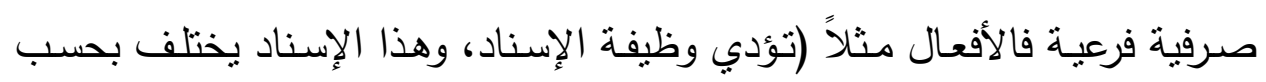

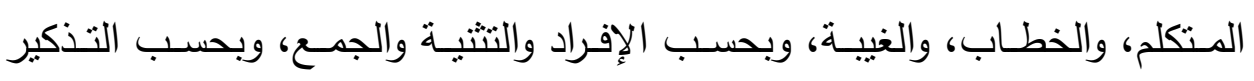




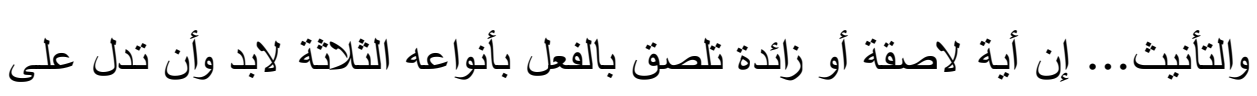

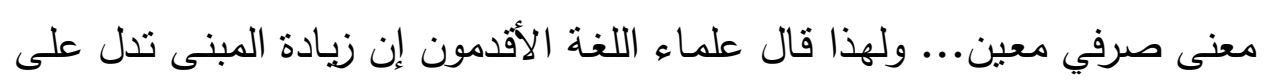

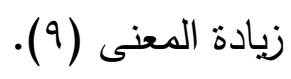

والتحليل الصرفي للمفردات يثري الدراسـة، ويكثف عن قيم تعبيرية وفنيـة

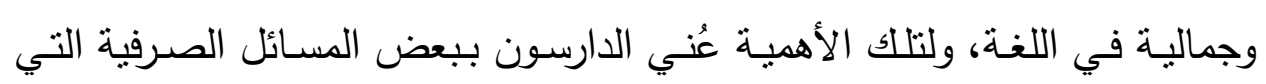
تخدم المعنى منل: تقسيم الكلمة من حيث الاسمية والفعلية والنظر إليها من حيث

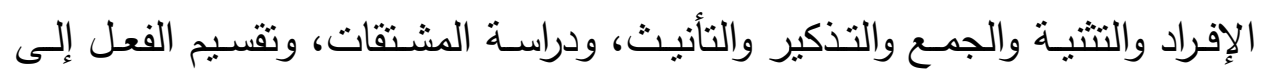

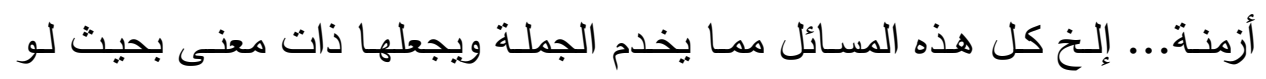

$$
\text { تغيرت وحداتها الصرفية تغيرت معانيها ( • (). }
$$

ومن أهم الوحدات الصرفية في اللغة: الفعل ويليه الوصف، ووفرة الأفعال في وتكرارها بنسبة عالية يجعله سمة أسلوبية، ولما كانت وفرة الفعل وأزمنته وأبنيته في النص سمة أسلوبية قد تؤثز في المعنى فقد هدفت في هذه الدراسة إلى بيان ذلك الأثر من خلال الثعر . ودواوين الشعر العربي تتطق بهذه الدلالة الصرفية، وقد اخترت القصائد

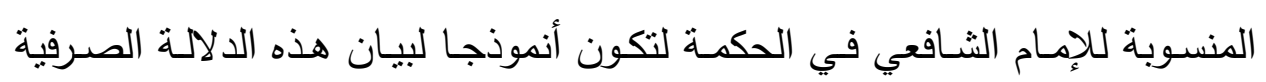
للفعل في شعر الإمام الثافعي. وقد عرف علمـاء اللغــة والنحو الفعل فـابن فـارس يقول: (الفـاء والعين

واللام، أصل صحيح ،بل على إحداث شيء من عمل أو غيره) (1') وجاء في لسـان العرب: (الفعل كنايـة عن كل متعد أو غير متعد، فعل احل يفعل فعلا وفعلا) (I) (I) ويعرفه سييويه قائلا: (وأمسا الفعل فأمثلة أخذت من لفظ أحداث الأسماء

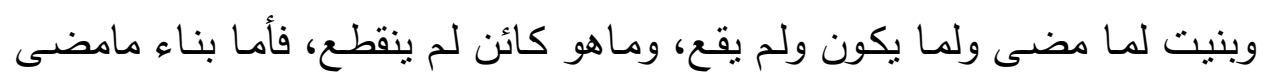
فـ (ذهب ـمع ومكث وحمد) وأمـا بناء مـالم يقع فإن قولك آمرا (اذهب واقتل

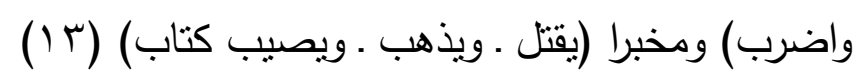




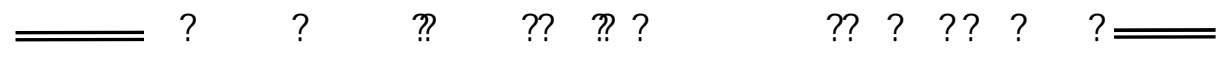

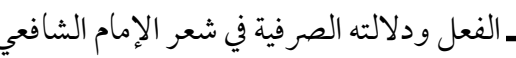

ويعرفه الزجاجي بقوله: (مادل على حدث وزمان) (ع ( )

وعرفه ابن هشام: (كلمة تدل على معنى في نفسـه) ا مقترنـة بأحد الأزمنة

الثلاثة (10)

وقد تأتي الأفعال بدلالات متقاربة ولكن لكل فعل مقام معلوم، من ذلك(أفاء

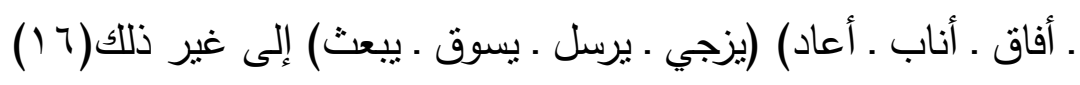




\section{التعريف بالشافعي:}

هو محمد بـن إدريس بـن شـافع الهاشـيـ...، أبـو عبــ الله، أحد الأئــة

الأربعة عند أهل السنة.

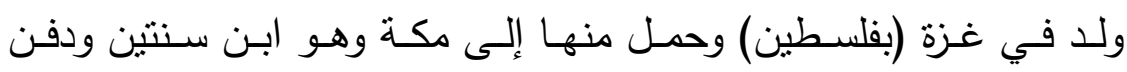

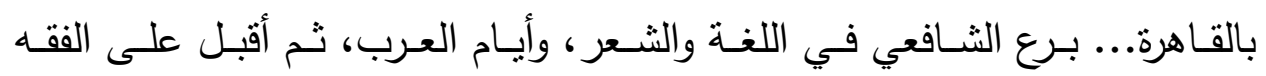

والحديث، وكان مفرط الذكاء وأفنى وهو ابن عشرين سنة (V l ).

وقد كان لشعر الثافعي مذاقا خاصـا تستطيع من خلالهه أن تميز بـه شعره

$$
\text { عن شعر الآخربن، ومن ملامح شعره (1) (1) }
$$

1 كثرة الحكم في شعره، ولاسيما تلك التي تحض على طلب العلم، والرضا بقضاء الله وقدره.

$$
\text { r ب الملوه من المدح والهجاء }
$$

r ـ قلة الصور الفنية الشعرية، وشعره، وصوره أشبه مايكون بشعر الفقهاء،

يغلب عليه الجانب المنطقي.

ع ـ قلة الوصف

ه ـ الطبع والعضوية

7 ـ خلوه تقريبا من الغزل والنسيب والحديث عن المرأة

ويشكل ديوان الثـافعي تطبيقا لموضوعات الصـرف بصفة عامـة وللفعل

خاصـة، حيث وردت بـه كل صـور الفعل الماضـي والمضـارع والأمر بكثرة شديدة كما سنرى.

وأولى السمات الأسلوبية اللافتة في قصائد الإمام الثافعي:

- سيطرة الفعل على لغـة الأبيات الثـعرية، ومعظم موضسوعات الثـاعر

تؤثز التعبير بالجمل الفعلية، حيث نجد أن شعر الأخلاق والأدب قد بلغت أبياته

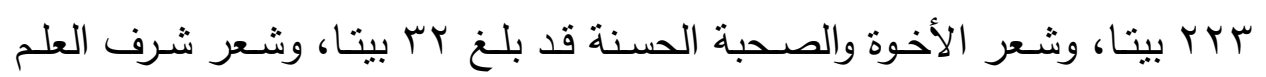

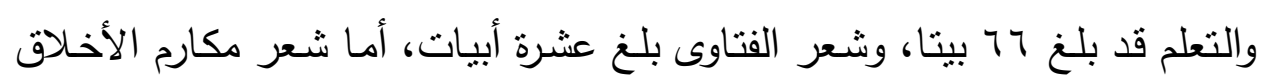


فقد بلغ هـ بيتا، وشعر الزهد والتصوف والعقيدة بلغ VI ا بيتا، وبلغ شعر الحكمة عشرين بيتا، أما الأغراض التقليدية فقد بلغت ب ب بيتا (19)

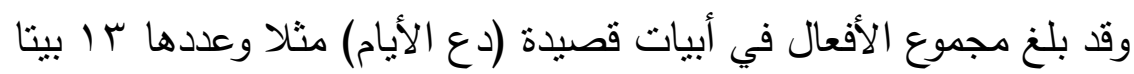

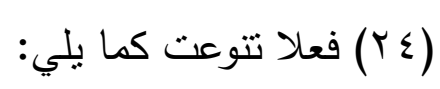

فعل الأمـر والذي بـأت بـه القصيدة حيث بـدأت بفعـل الأمـر (دع) ممـا يعطي دلالة معينة من أول وهلة بأن موضوع القصيدة هو النصح والإرشاد وإيراد

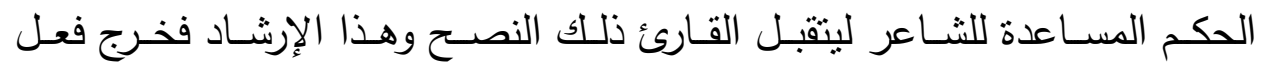
الأمر (دع ـطب ـن تشتر) من معناه الحقيقي وهو طلب فعل الثيء إلى المعنى المجازي وهو النصح والإرشاد وكثرت الأفعال المضارعة الواقعة في أسلوب

$$
\text { النهي (لاتجزع · لاتر · لاترج). }
$$

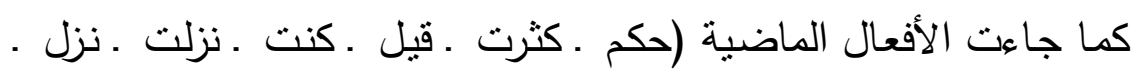
ضـاق) وكلها تدل على خبرة الثـاعر في الحياة والتي يرويها في كثرة استخدامه للفعل الماضي. ثم يأني الفعل المضارع المثبت (تشاء ـ تكون ـ يغطيه ـ يدوم ـ ينقصه ـ يزيد

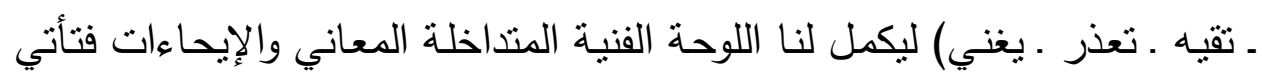
الحركة والاستمرارية من خلال هذه الأفعال المضارعة. ونجده في مقطوعـة (سـهام الليـل) والمكونـة من ثلاثنة أبيات وقد ازدانت بالأفعال الدالة على الحركة حتى أنه استخدم ثلاثة أفعال مضارعة في بيت واحد يقول:

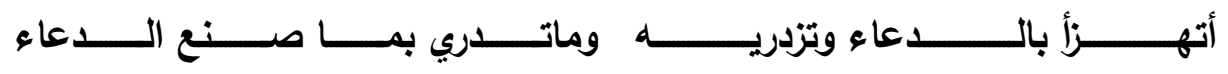
فالأفعال (تهزأ تزدري ت تدري) تتوع مجيئها على أكثر من حالة وهيئة حيث ورد الفعل الأول (تهزأ) مقترنا بأسلوب استفهام استتكاري وعطف عليه الفعل الثاني (تزدري) وجاء الفعل الثالث (تدري) مقترنا بنفي. 


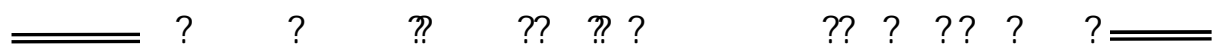

ويأتي فعل رابع ماصيا منفيا (ماصنع) وبكون بهذا قد استخدم أربعة أفعال

$$
\text { في بيت واحد قصير . }
$$

ونراه في المقطوعة ذاتها يستخدم أربعة أفعال أخرى في البيت الثالث يقول

$$
\text { واصفا الدعاء (سهام الليل): }
$$

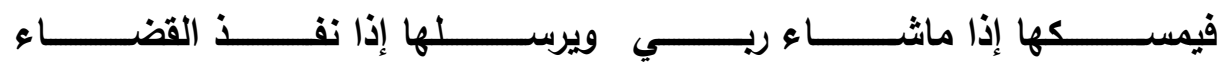

فنجده يستخدم المضارع (يمسكها يرسلها) والماضي (شاء ـ نفذ) ليرسم

مقطوعة فنيـة غنية بـالحكم من ثناثة أبيات كما نلاحظ أيضـا استخدامه للصيغة

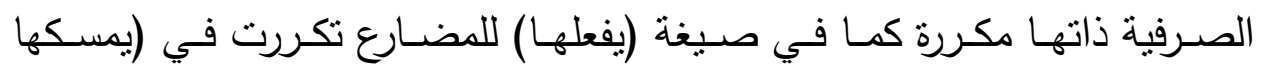

$$
\text { ويرسلها)، وصيغة الماضي (فعل) كما في (شاء ونفذ). }
$$

ومن الظواهر اللافتة؛ احتشاد الأفعال في المقطع الحواري، فهي لا تتباعد كثيرا بحيث تتوزع وتتناثر في اللغة، بل تتقارب وتتوالى على لسان الثـاعر محدثة تراكمـا في المقطع الحواري لكن الحـوار عند الثـافعي في غالبهـ حوار متخيل، وأحيانا يكون حوارا واقعيا كما في حوار الثاعر مع بشر المريسي ومناظرته له في حضرة هارون الرشيد حيث احتشدت الأفعال في هذا المقطع يقول: (· ب):

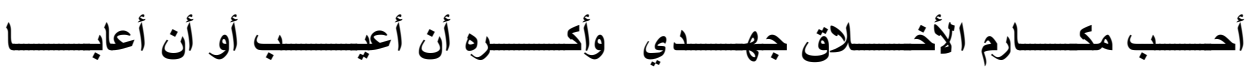

وأصــفح عــن ســباب النــاس حلمـــا وشـــر النـــاس مـــن يهــوى الســـبابا

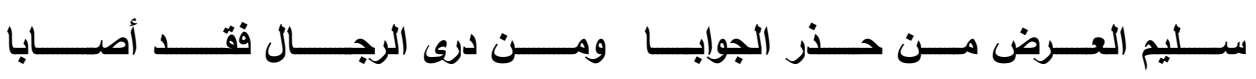

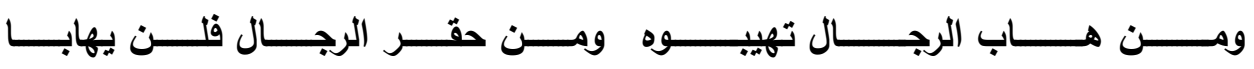

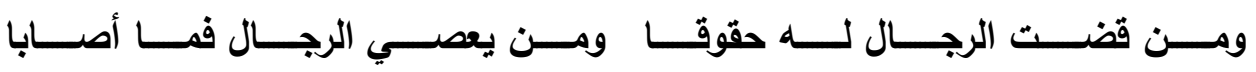
هذه مقطوعة من خمسة أبيات يتحدث فيها عن فضائل الرجال عامة وعن

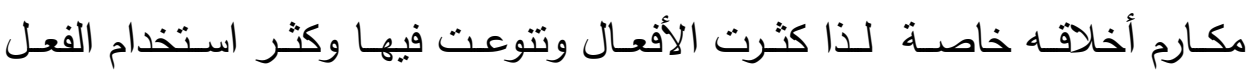
المضارع المبدو بهزة المتكلم (أحب ـ أكره ـ أعيب ـ أعابا ـ أصفح) وتوحي هذه ونئ

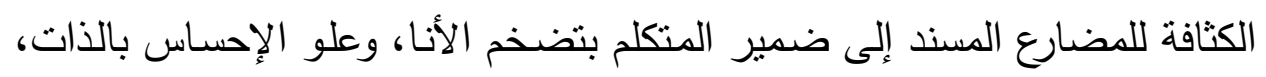


وتوهجهـا. وازدحـام الأنـا معـادل شـعوري لفـرط ثــة الثـافعي بنفسـه، وإحساسـه بمسؤوليته تجاه مبادئه، وتحقيق رسالته.

وهذه الظـاهرة قد احتشـدت في قصـائد الثـافعي ومقطوعاتـه فغلب عليها استخدام الفعل المضارع الدال على التكلم سواء المبدوء بهمزة التكلم أو المتصل بياء المتكلم أو المتصل بتاء الفاعل.

وقد حصرنا تلك الأفعال وهي: (حرمت . دهيت كلمته . خليته . سكت .

عييت ـ عفوت ـ لبست ـ أصبته ـ علقت (مرتان) . قاسمته ـ تصفحت ـ أبرأته قلت . كنت أصبحت ـ لست ـ لازلت ـ غذيتتي . هديتتي رمت ـ ضقت ـ هبته ـ خفته ـ هوبت ـ سبني . تزايدت ـ وجدتي . خانني . رأنكا ـ كنت ـ قلت ـ اشتريت ـ رآني ـ رأيته شئت . رعيت ـ أجبت ـ كرهتتي ـ أتاني . ضقت ـ قنعت صنت . جفاني . طردت . بسطت . برئت . تورعت . قنعت . صرت . . وجدتتي . أنزلني . سألتهم . حشرت . ملأت .

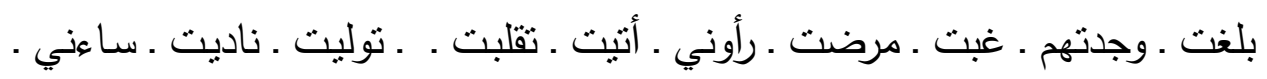
سرني . تذرعت . عشت . جاءني . وافيتها ـ بليث . وجدت . لزمته . حشرت . غبت .

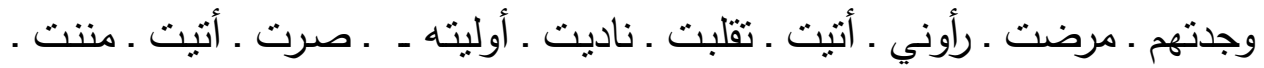
غلبت ـ شكوت . . أخبرني عبرت . تتكرت ـ شهدت . أرشدني . أكداني وجدت . علمت . مرضت ـ برئت . رأيت ـ بلوت . جردت ـ قطعت ـ زرتتي أقرضته ـ أظهر . أثكو . أستمطر . أعجب . لم أر . لم أضح . أرى . أنثر . أنظم . سأكتم . لأنثر .

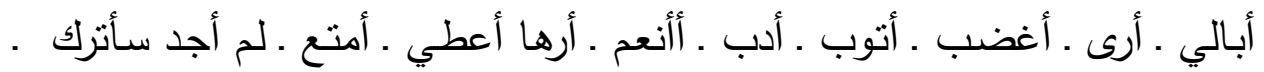
أموت ـ أعيب أحب أكره ـ أصفح . أعابا أكون أكتمه . أزيد ـ سأضرب أكره ـ أنال . أجد ـ أشهر ـ أخلص أصون أجعلها . لم أحذر ـ أثنعر أسمع . أرى ـ أدفع . أقرع أتضرع ـ أدعو ـ أهتف لم أرض ـ أهجو ـ أسود ـ أعزيك ـ أهين ـ تكويني ـ تكفيني .

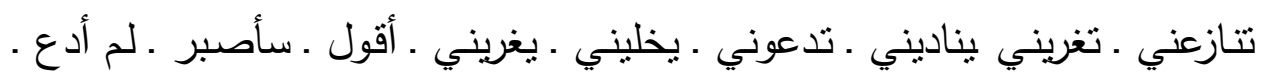
أبالي . يعالجني . أرفع ـ تعاظمني . أكون ـ أصبر . أهنأ . أسعى أنفع أسلم . أترك . 


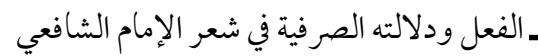

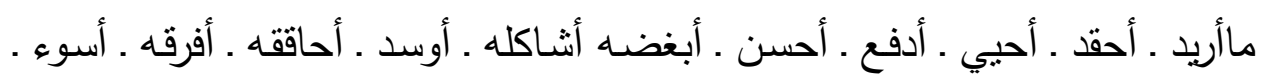

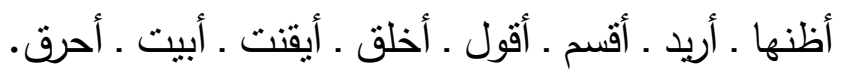

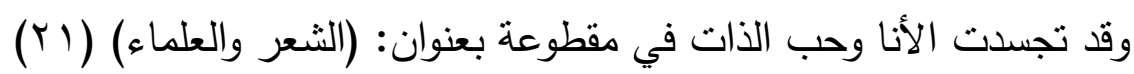

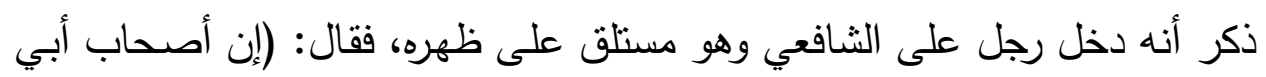

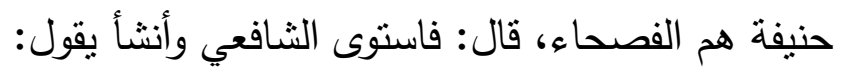

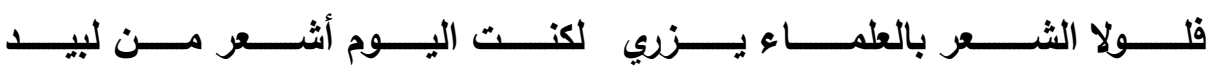

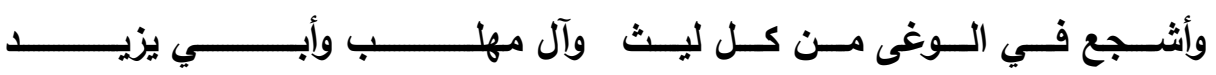

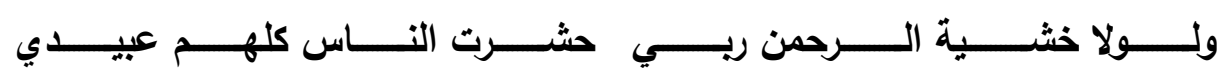

بالإضـافة لما يفوح في البيت من معاني التقة الزائدة عن الحد ولاهذا

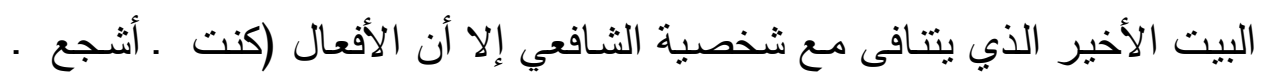

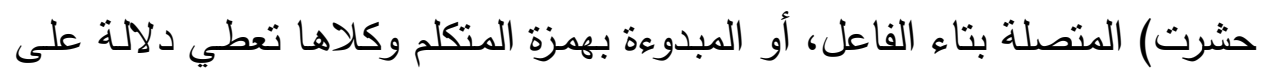

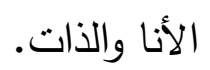

كما كثر استخدامه للفعل الماضي (حذر ـ دري ـ أصاب هاب) مع وروده

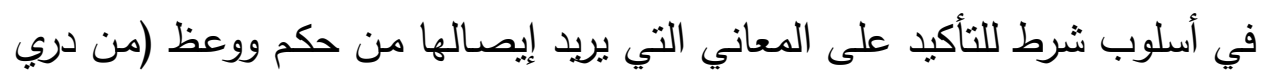

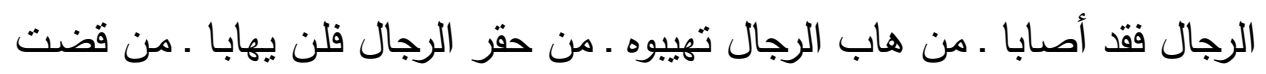
الرجال له حقوقا... فما أصابا).

هذا مع تكرار الجذر الواحد في البيت نفسه كما في (هاب ـ تهييوه ـ بهابا)

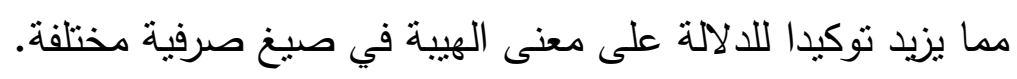
وقد لاحظنا انتشار هذه الظاهرة بشدة في أبيات الديوان حتى أستطيع القول

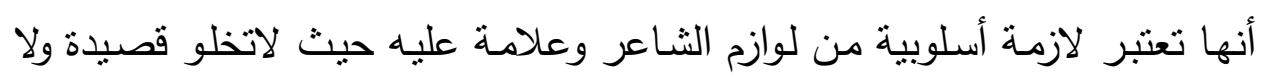

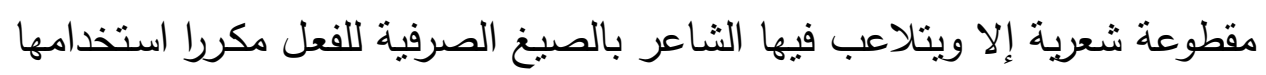
في البيت الواحد أو البيتين 


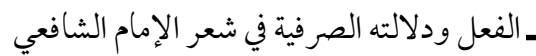

وأحيانـا بستخدم الصيغة الواحدة مرة مثتبة وأخرى منفيـة في البيت نفسـه يقول في:

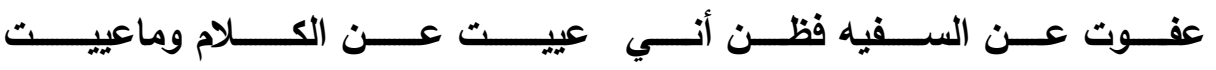
ويقول أيضا:

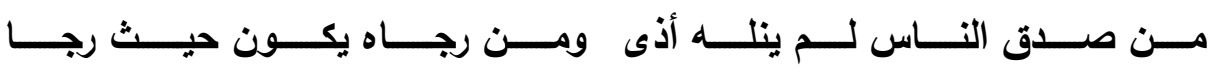
ومنه البيت الثهور في الفرج والأمل حين يقول:

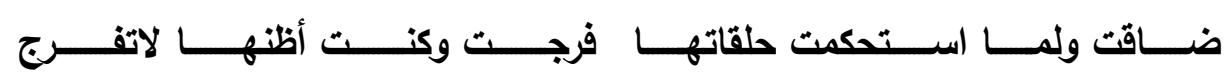
ومنه:

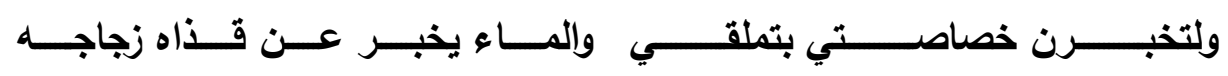
ومنه أيضا:

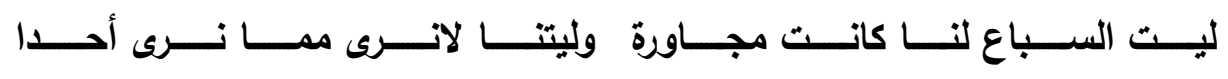
ومنه كذللك:

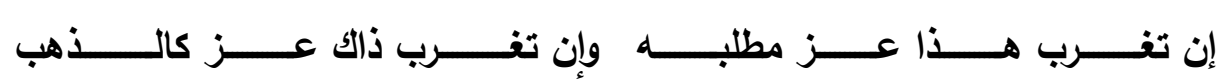
وأيضا قوله:

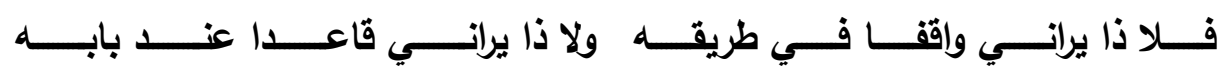
ومنه قوله:

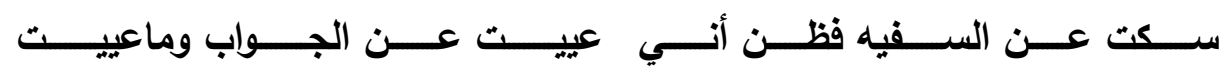
ونراه في مقطوعة بعنوان: (أيادي مضت) بستخدم الفعل المضعف (مل) في أكثر من ثلاتة أبيات بصيخ صرفية مختلفة من أصل ستة أبيات هي عدد بعد أبيات المقطوعة، يقول:

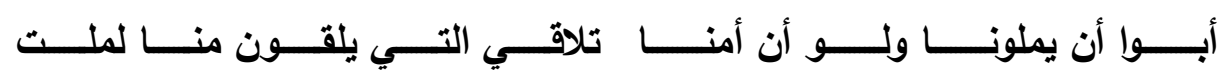

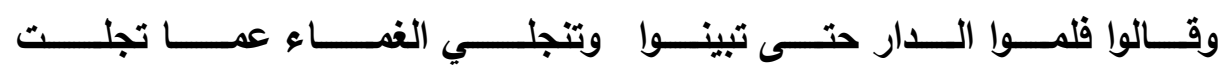




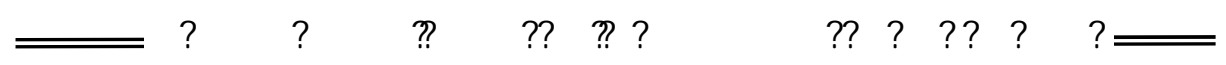

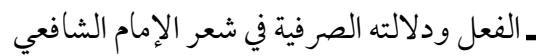

$$
\text { ثم يقول أيضا في نفس المقطوعة: }
$$

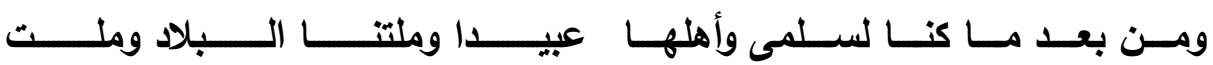

ومنه تكراره للفعل (أراد) أكثر من مرة في البيت الواحد، يقول:

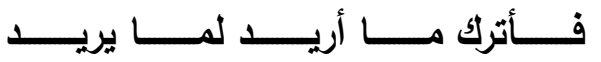

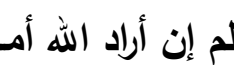

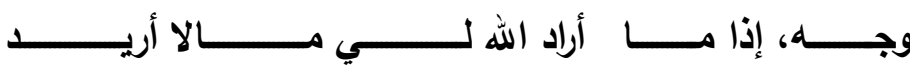

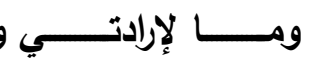

ومنـه اسـتخدامه للفعـل (رأى) كمـا في يقول في مقطوعـة بعنـوان :(لعلـه

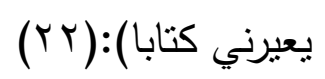

سأل الشافعي محمد بن الحسن أن يعيره كتابا فكتب إليه بهذه الأبيات:
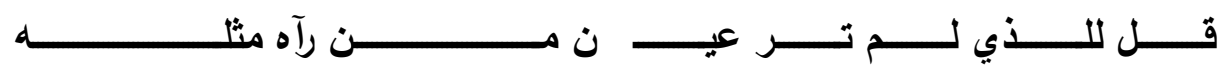

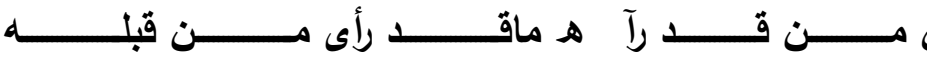

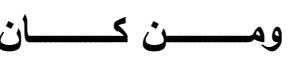

ومنـه استخدامه للفعل (زار) في مقطوعـة بعنوان: (زيارة أحمد بن حنبل)

كان الإمام أحمد بن حنبل من خواص أصحاب الثـافعي وكان الثـافعي

يأتيه إلى منزله فعوتب في ذلك فأنشد:

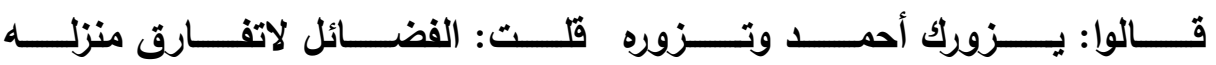

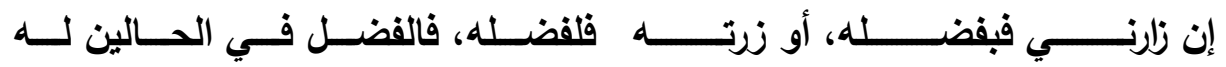

ومنه استخدامه للفعل (عاد) في مقطوعة بعنوان: (أحكام الهوى) (؟ ب)

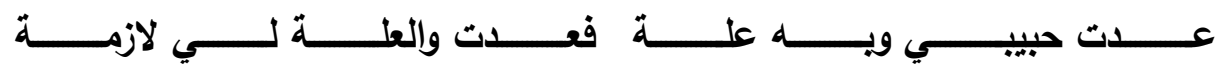

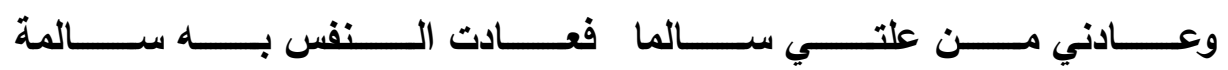

ثم ينوع في تكرار جذر آخر (صح) فيستخدمه مرتين في الأولى فعلا وفي

الثانية مصدر في المقطوعة نفسها يقول: 


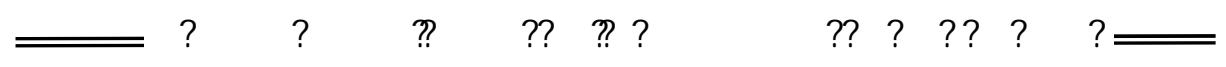

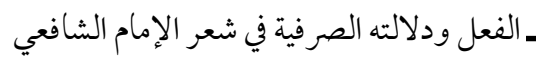

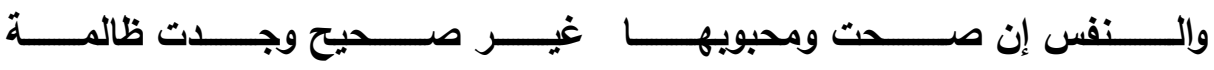

ويكرر جذرا آخر في المقطوعة ذاتها (حكم) يقول في البيت الرابع:

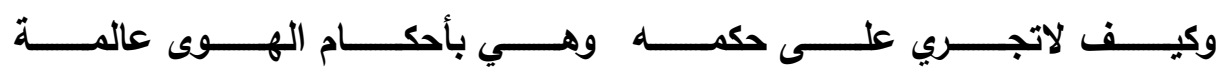

ومنه تلاعبه بالفعل (يزن) فيكرره مرثين بالصيغة نفسها يقول:

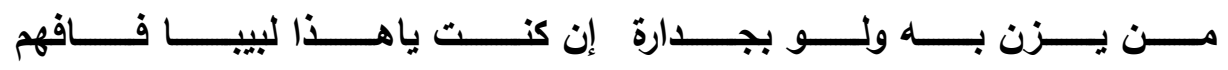

ومنه قوله:

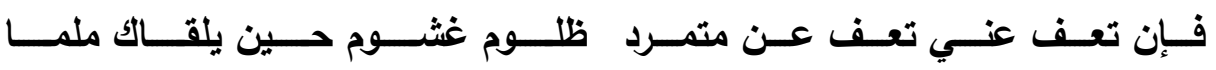
ويستخدم الفعل (رأى) في مقطوعة واحدة مكونـة من خمسة أبيات بعنوان

(كامل المعاني) حيث نراه يكرره خمس مرات في بيتين انثين يقول: (ب): يقول:

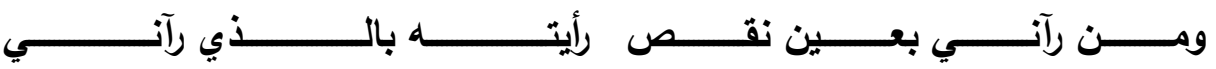

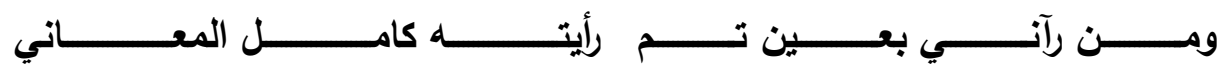

ومنه تكراره للفعل (شاء) أكثر من مرة حيث يقول (TT)

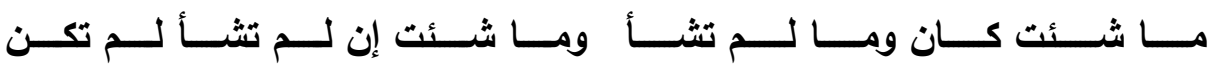

ويتلاعب بالفعل (زان) يقول:

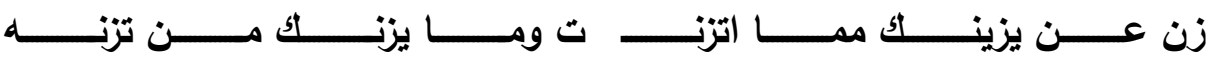

ومنه تكرار الأفعال مع أسلوب الشرط وهي كثيرة منها: (YV)

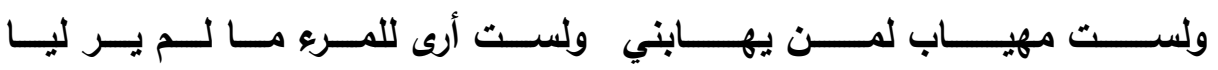

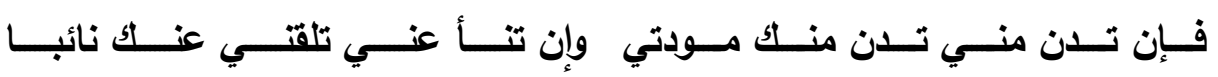

$$
\text { ومن التكرار كذلك قوله (r^): }
$$

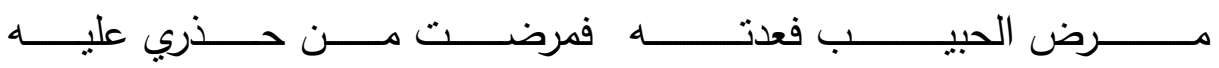

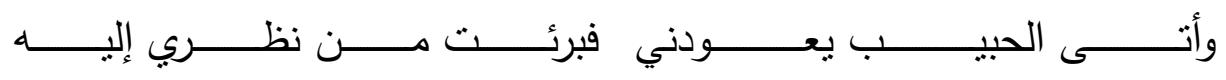


وهكذا فإنـه لا تخلو صفحة مـن صفحا ت الديوان إلا وقد استخدم هذه

الظاهرة.

كما أنه قد يستخدم الأفعال المتضادة كما في قوله:

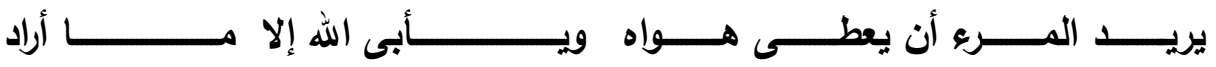

والفعل كما هو معلوم يدل على حدث وهو بذلك أكثر دلالة على الحركة

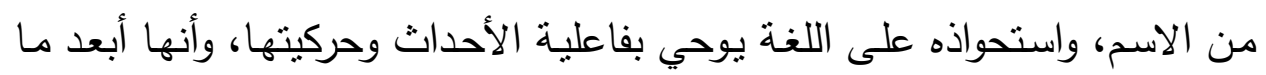
تكون عن الثبات والاستقرار والديمومة.

وهذه المقطوعة السـابقة (أيادي مضت واند) والمكونـة من ستة أبيات اشتملت

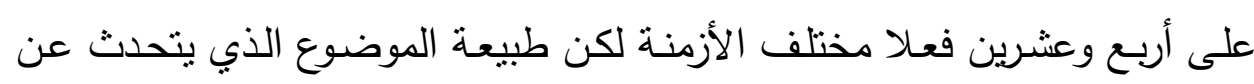
تجارب في الماضي اضطرت الثـاعر لحثد الأفعال الماضية في المقطوعة والتي بلغت سبعة عشر فعلا في هذه المقطوعة فقط وهي: (جزى ـ أزلفت ـ زلت ـ خلطونا

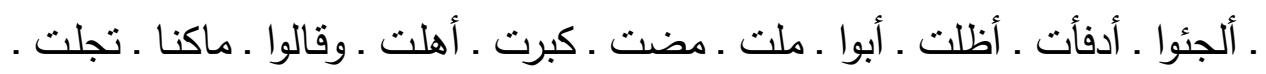

ملتنا . ملت).

وتوظيف الفعل الماضي في الحديث عن الفترات السابقة والتاريخ يعبر عن الثخصية العربية التي تعترش الماضي وتتعلق به فتتغلها عن حاضرها فيستغرقها في الماضي سلبا وإيجابا (Y) وجاء فعلا واحدا للأمر وهو (فلموا)، وستة أفعال مضارعة وهي (يملونا . تلاقي • يلقون . ستجزي . تبينوا ـ تتجلي). وقد احتشد الفعل الماضي في أبيات الديوان وقد حصرنا الأفعال الماضية لنية في أبياته فكانت وند وتتراكم الصيخة الفعلية في المقاطع الحواريـة التي يتخيل فيها حوار مـع مخاطب، إذ يحنتـد تسعة وأربعون فعـلا في قصيدة بعنوان (سيفتح بابـا) والتي يتوجه فيها إلى مخاطبه في خمسة وعشرين بيتا من الثعر . 
وتتــير هـذه الأبيـات إلى حفاوتهـا بالفعل المضـارع، وغلبتـه على لغــة الثاعر أكثر من الماضي والأمر ، وهذا الحضور الطاغي للفعل المضـارع ، يوحي بحيوية الأحداث واستمرارها عبر الأزمنة وعدم اقتصارها على زمن معين لأنها حكم

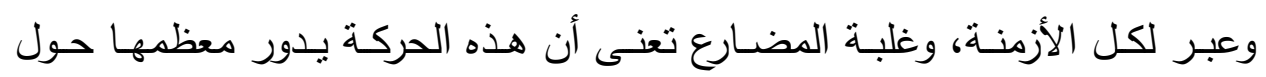

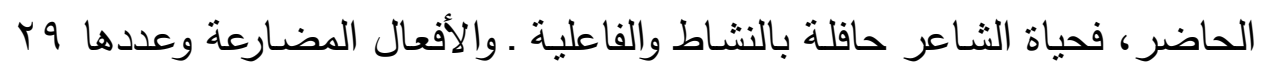
فعلا في هذه القصيدة وهي (سيفتح • يتسع ـ تضيق . يجدي . ير . يهاب ـ تأته ـ أتيح

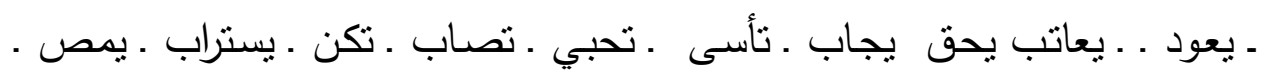

يسنطاب ـ تجل ـ يمص • يعاب ـ يقود ـ تدر ـ يفر ـ تغني • يلاقي • يهوي • يردي).

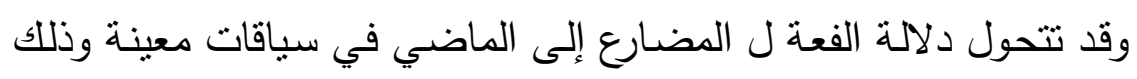

بقرائن لفظية أو معنوية خاصة بالزمن الماضي وذلك منل (لم، لما) ( • (ب) . وقد وردت كثيرا في أبيات ديوانه منل: (لم أر ـلم يزد ـ لم أضسح . لم تأب .

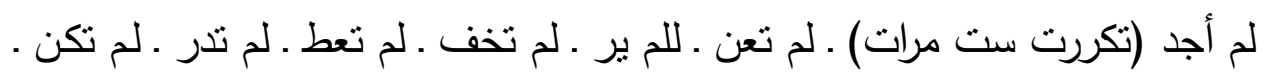

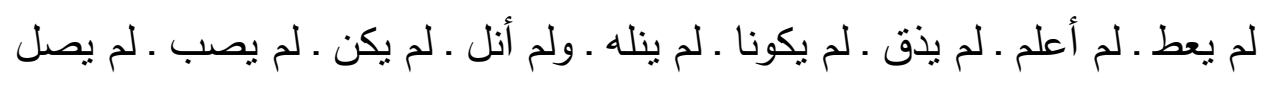

أما الفعل الأمر فقد ورد سبع مرات (هون ـ تبين ـ اقتصد ـ أقلل ـ فأحسن .

دع ( ميز)

أمسا الماضي فقد ورد فيها 10 مرة (سد ـ ضقت ـ هبته ـ خفته . عوفيت .

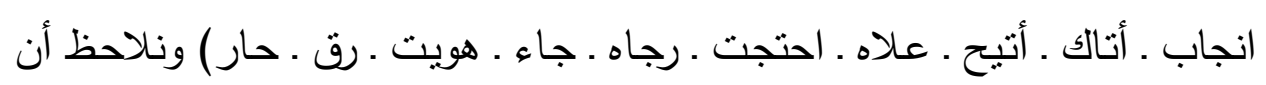
الفعل الماضـي اتصل في معظمـه بتـاء الفاعل للمخاطب المذكر ممـا يؤكد على لهـ حرص الثاعر على توجيه الخطاب إما لمخاطب حقيقي أو متخيل.

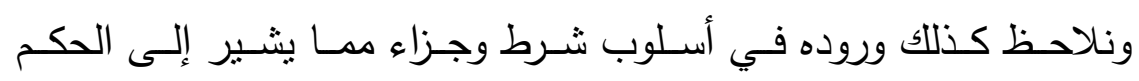
والمواعظ فيقول مثنا:

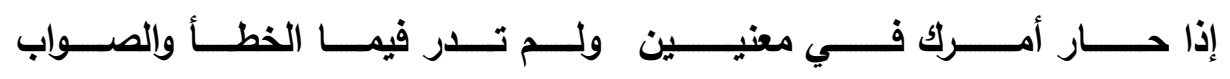
وجواب الثرط في البيت الذي يليه حيث يقول: 


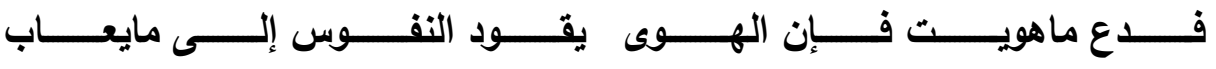

ويرتفع الأداء الفعلي في الفعلين (يخالطني، يوافقني) لأن المعنى الصرفي

لصيغة (يفاعِلُ) هي المشـاركة وهذا يعنى أن الفاعل والمفعول بـه قد اثتركا في الحدث، بحيث (يفعل أحدهما بصاحبه فعلا فيقابله الآخر بمثله، فتتسب الفاعلية للبادئ، بينما تتسب المفعولية للمقابل كما أنها تضيف قيمة تعبيرية لاتصالها بياء المتكلم، وهي تقوم هنا بوظيفة نحوية هي الدلالة على المفعولية، (اب).

$$
\text { يقول في مقطوعة بعنوان (الناس داء): }
$$

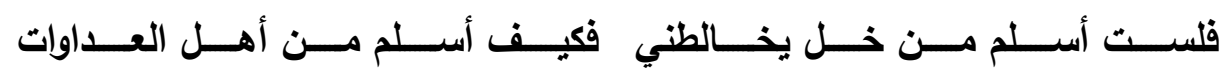
ويقول في مقطوعـة أخـرى بعنـوان: (تصفحت إخـاني) واصـفا الخـل أو الصديق الذي يتمناه: - مان

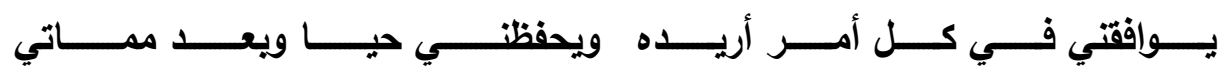
مما يثير إلى رغبة الثاعر الملحة في الاندماج مع الغير والمشاركة. وتتـير كثرة صـيغة فعل الأمـر في أثـعار الثـافعي إلى نزعـة النصـح

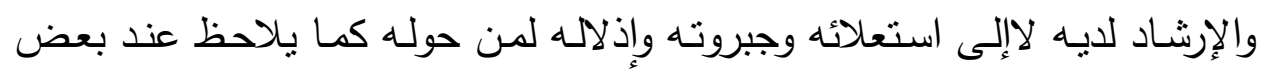
الثعراء، وقد ورد فعل الأمر في أبياته (107 (1) مرة. وبعد هذا التحليل الإحصائي للصيغة الفعلية بتضح أن الفعل ظاهرة لافتة

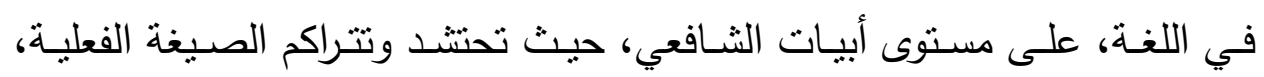
وخصوصـاً الفعل المضـارع، الصيغة الأثيرة لدى الثـاعر ودلالته على الحسال أو أو الاستقبال تعبر عن تطلعاته المستقبلية وتحركاته حول الحاضر . وقد ورد الفعل المضارع في الديوان rTV مرة. 


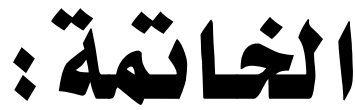

مع نهاية البحث نلاحظ الآتي:

ا ـ احتشاد الأفعال في الديوان المنسوب للثافعي فقد وصلت إلى (T P V ) فعلا

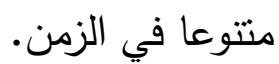

r تتـوع الصـيخ الصـرفية الزمنيـة للأفعـال، فقد اسـتخدم الماضـي والمضـارع والأمر .

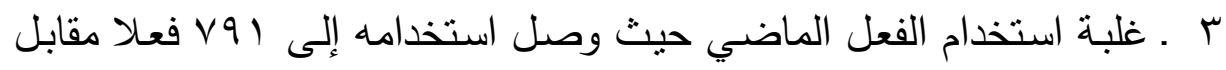

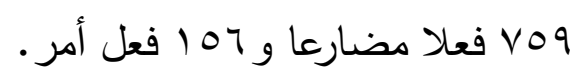

ع . كثثرة استخدام الفعل الدال على التكلم سواء كان ماضيا أو مضارعا مبدوءا بهززة التكلم أو مسندا لياء المتكلم أو لتاء الفاعل للمتكلم. ه ـ كثرة استخدام الجذر الواحد بصيغ صرفية مختلفة في الزمن. 7 البيتين.

. طبيعة موضوعات الثـاعر قد فرضت الحشد الفعلي للأبيات وفرضت كذلك تتوع الصيخ الصـرفية الزمنيـة وقد كثر الأمـر في شعر النصسح والإرشـاد

$$
\text { وليست وليدة حب الذات. }
$$

أمسا الماضي والذي احتتد كثيرا في القصائد والمقطوعات فقد عبرت عنه موضوعات الحكم والوعظ ومكارم الأخلاق. أمسا المضـارع والذي تقارب مـع الماضـي ليرسم لنـا صسورة حركيـة نابضــة بالحياة صالحة للحاضر والمستقبل. 
وأخيرا فإن اختيارنا لشعر الإمام الثافعي كان متعددا ومقصودا لما يتميز

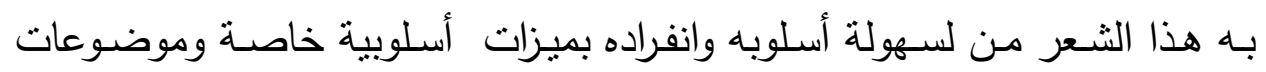

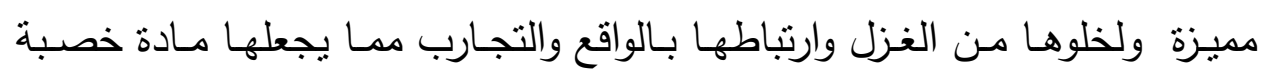
للتطبيق والتحليل. ولكن واجهتـا صسعوبة اختلاف الآراء حـول نسـب الأبيات للثـافعي ممـا حدى بنا للبعد عن هذه الخلافات حيث تخخر كتب الأدب والترام بها واعتمدنا على ولى أحد شروح الديوان والتي استقينا منها مادتتا العلمية هده لإندات 


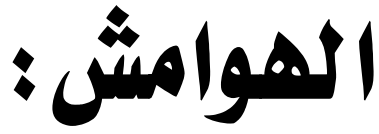

( (1) أقسام الكلام العربي من حيث الثكل والوظيفة صب • r، فاضل مصطفي الساقي، مكتبة

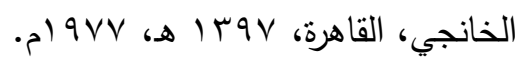

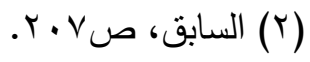

مناهج الصرفيين ومذاهبهم في القرنين الثالث والرابع من الهجرة / حسن هنداوي / دار القلم

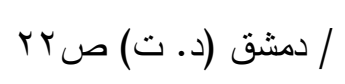

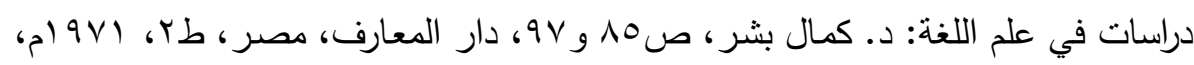

المغني الجديد في علم الصـرف، د. محمد خير حلواني صوَ، دار الثـرق العربي،

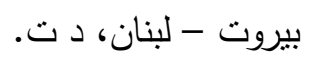

(0) الأزمنة في اللغة العربةـ تأليف / فريد الدين آيدـ دار العبر للطباعة والنشر ـاسطنبول

$$
\text { (997 الم صرجع السابق صץ المب }
$$

(V) الصيغ الصرفية ودلالتها في ديوان عبد الرحيم محمود / دراسة وصفية للباحثة / حنان جميل

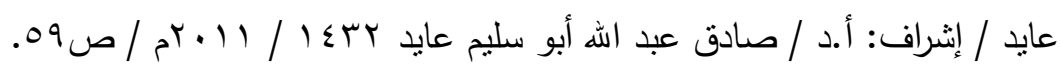

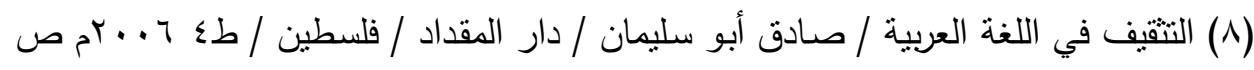

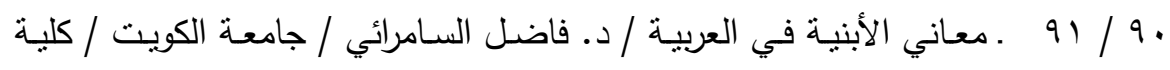

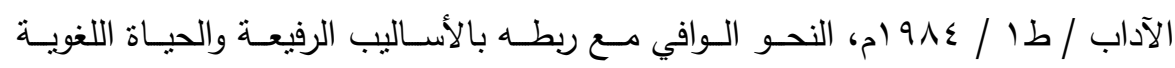

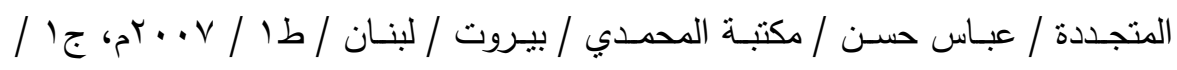

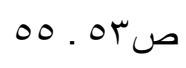


(9) أدب الكاتب، ابـن قتنيـة، أبو محمد عبد الله بـن مسلم: شـرح علي فاعور ، دار الكتب

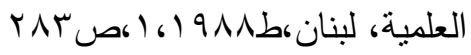

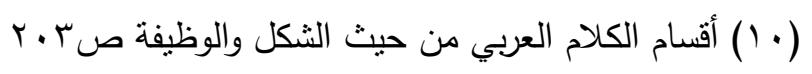

(1) (1) معجم مقاييس اللغة / أحمد بن فارس / تحقيق: عبد السلام هارون / دار الكتب العلمية .

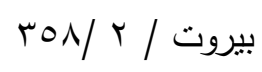

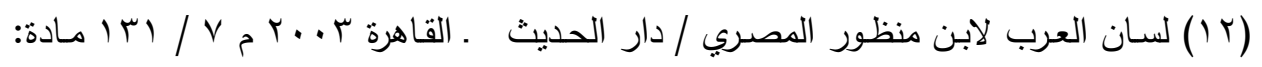

فعل

(1 (1) الكتاب / أبو بشر عمرو بن عثمان بن قنبر تحقيق: عبد السـلام هـارون / مكتبة

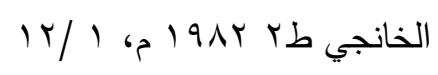

( ( ) الإيضـاح في علل النحو / أبو القاسم الزجاجي / تحقيق: مازن المبارك / دار النفائس /

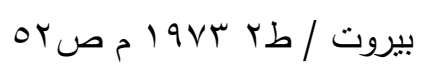

(10) الجامع الصغير في النحو / لابن هشام الأنصاري .ت / أحمد محمود الهرميل / مكتبة

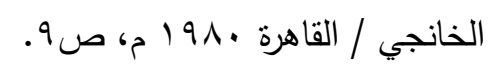

(7 (1) أبنيـة الأفعـال / دراسـة لغويـة قرآنيـة / د. نجـاة عبد العظيم الكوفي / دار التقافـة للنشـر

$$
\text { والتوزيع 1919 ام ص } 7 .
$$

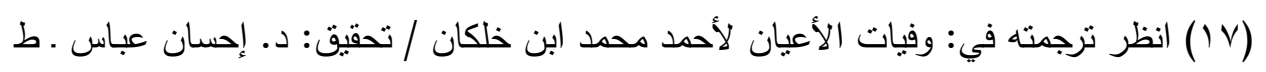

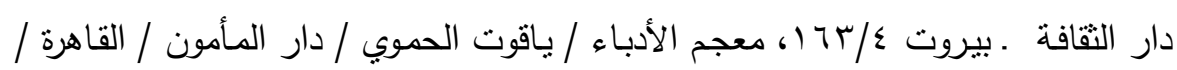

$$
\text { נ.rNI / I D }
$$

(1) (1) ديوان الإمام الثافعي • حققه / عبد الرحمن المصطاوي ـ دار المعرفة ـ بيروت ـ لبنان .

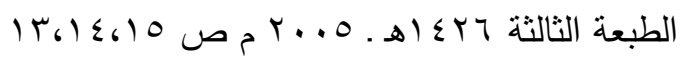

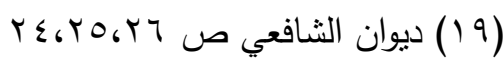

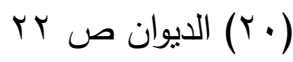


(Y) الجوهر النفيسفي أشعار محمد بن إدريس / جمع محمد مصطفى .طبعة النيل بمصر ،

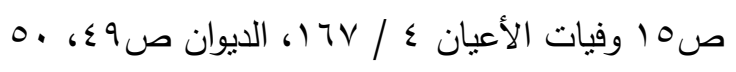

(Y (Y) مقامات الحريري / القاسم بن علي الحريري البصري / طبعة بيروت §/؟ 9، المحمدون من

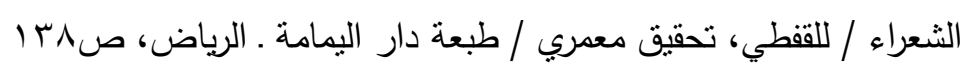

$$
\text { 0. إب) }
$$

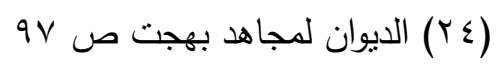

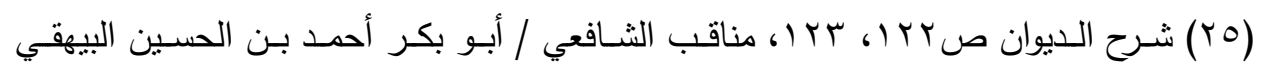

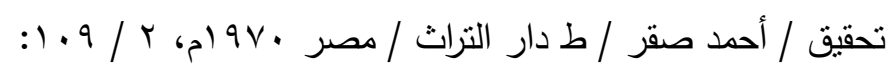

$$
\begin{aligned}
& \text { (דץ ( الديوان r } \\
& \text { I K الديوان (YV) }
\end{aligned}
$$

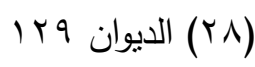

(Yq) البناء الصرفي في الخطاب المعاصر ـ دراسة في الألفاظ التراثية والمحثثة / د: محمود

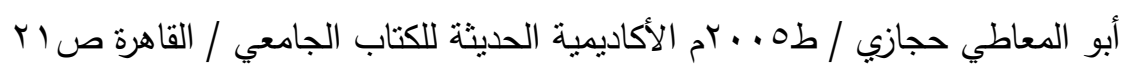

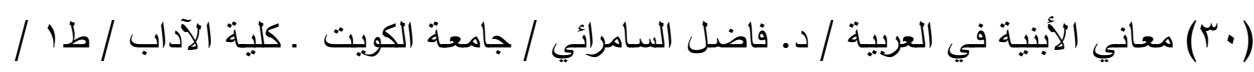

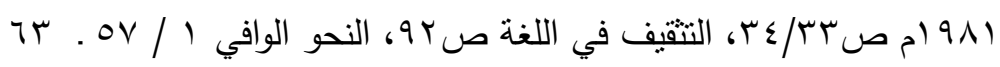

(1) أقسام الكلام العربي من حيث الثكل والوظيفة، ص بو r. 


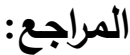

ا، أبنية الأفعال / دراسة لغوية قرآنية / د. نجاة عبد العظيم الكوفي / دار النقافة للنشر

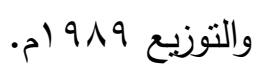

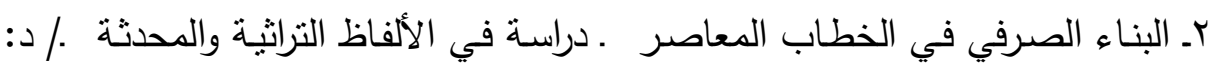

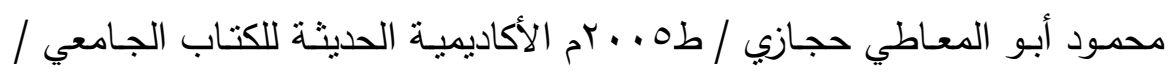

القاهرة

r ـ التقفيف في اللغـة العربية / صـادق أبو سليمان / دار المقداد / فلسطين / طع

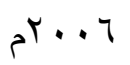

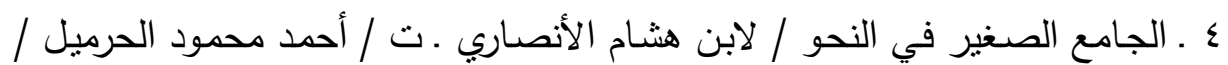

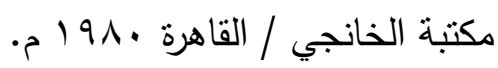

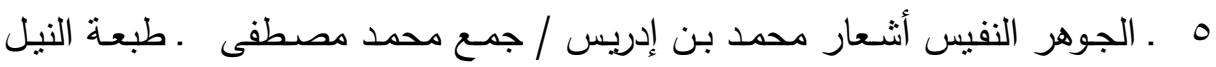

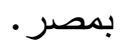

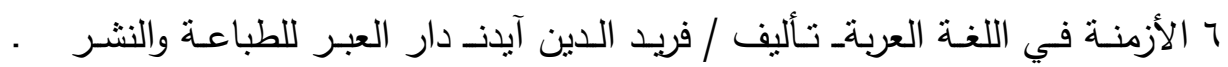

$$
\text { اسطنبول } 99 \vee
$$

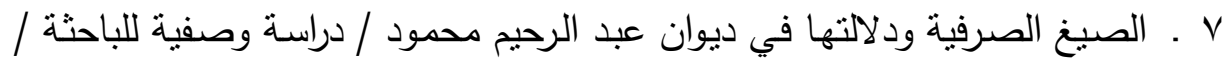

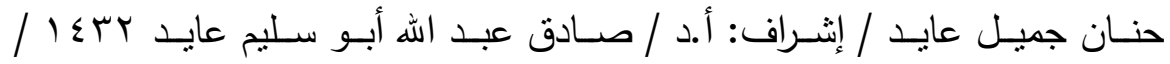

$$
\cdot{ }^{2}+111
$$

^. الكتاب / أبو بشر عمرو بن عثمان بن قنبر ـ تحقيق: عبد السلام هارون / مكتبة

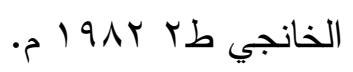

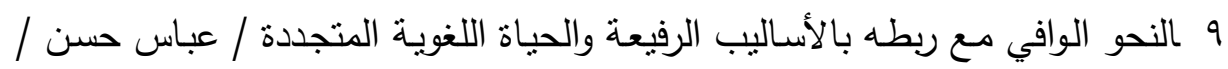

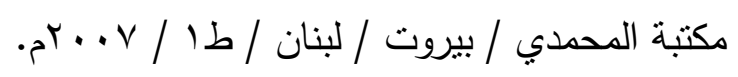

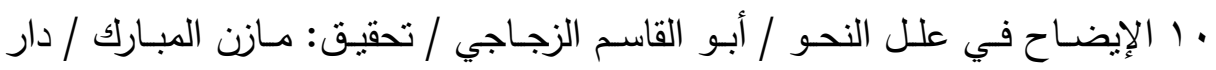

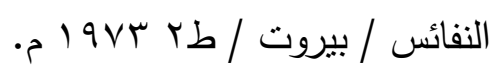

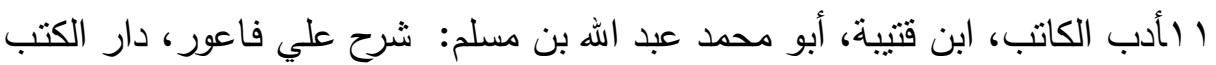
العلمية، لبنان،ط1919 16، 1.

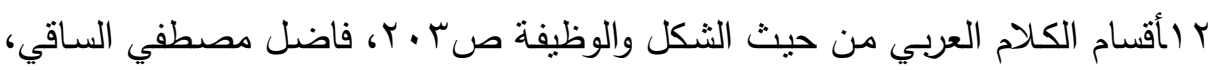

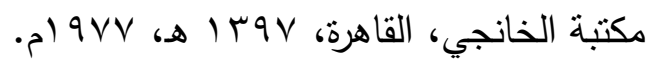

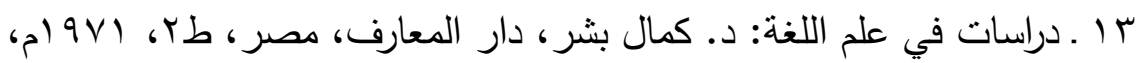




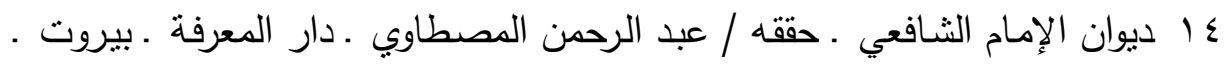

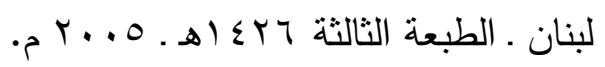

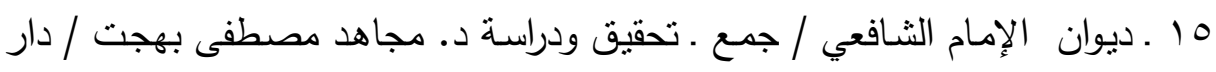

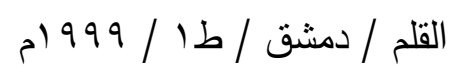

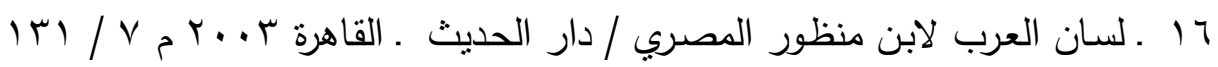

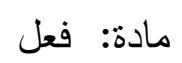

V V معاني الأبنية في العربية / د. فاضل السامرائي / جامعة الكويت / كلية الآداب / كابل

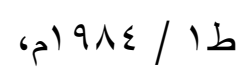

1 ا ـ معجم مقاييس اللغة / أحدد بن فارس / تحقيق: عبد السلام هارون / دار الكتب

$$
\text { العلمية . بيروت. }
$$

19 ـ المغني الجديد في علم الصـرف، د. محمد خير حلواني صوب، دار الثـرق

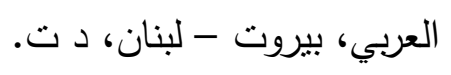

• r ـ المحمدون من الثعراء / للققطي، تحقيق معمري / طبعة دار اليمامة ـ الرياض.

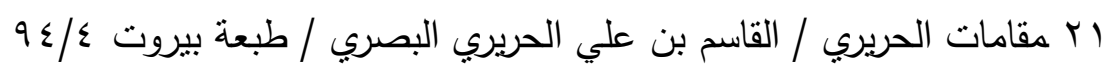

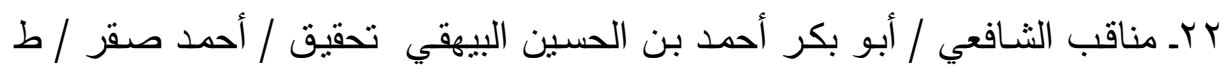

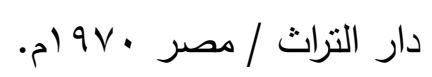

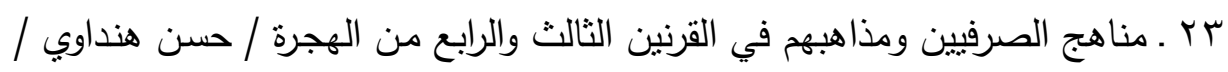

$$
\text { دار القلم / دمشق (د. ت) }
$$




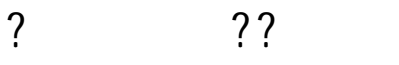

\begin{tabular}{|c|c|}
\hline $\begin{array}{c}\text { حف } \mathrm{J} \text { ? } \\
\text { ? }\end{array}$ & 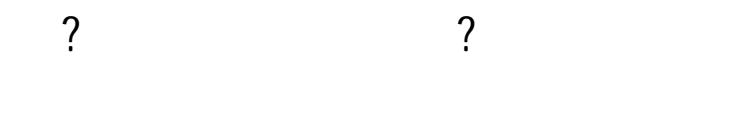 \\
\hline V90 & المقدمة \\
\hline 795 & الصيغة في الاصطلاح \\
\hline 797 & الصيغة الزمنية الموضوعة للفعل \\
\hline 799 & الوحدات الصرفية فى اللغة \\
\hline 801 & التعربف بالثافعي \\
\hline 801 & السمات الأسلوبية اللافتة في قصائد الإمام الثشافعي \\
\hline 813 & 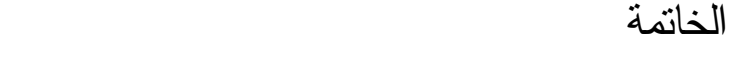 \\
\hline 815 & 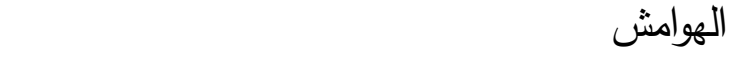 \\
\hline 818 & 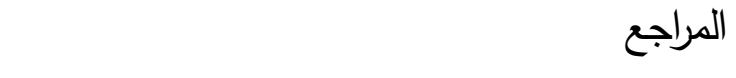 \\
\hline 820 & فهرس الموضوعات \\
\hline
\end{tabular}

